日本メドラッド社製CT用自動注入器(型名：MCT320P) 及び 根本杏林堂製CT用自動注入器に適合する。

\section{【警 告】}

(1)ショック等の重篤な副作用があらわれることが ある。

(2) 本剤は尿路・血管用造影剂であり、脳槽・脊蹃 造影には使用しないこと。

【禁 忌】(次の患者には投与しないこと)

(1)ヨードまたはヨード造影剂に過敏症の既往歴の ある患者

（2）重篤な甲状腺疾患のある患者

[ヨード過鄱に対する自己調節メカニズムが機能

できず、症状が悪化するおそれがある]
【副作用】

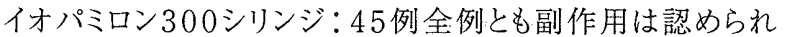
なかった。(承認時)

イオパミロン 300 : 総症例 3,751 例中 190 例 (5.1\%) に副作 用が認められ、主な副作用は嘔気 35 件 $(0.9 \%$ )、発疹 31 件 $(0.8 \%)$ 、熱感 28 件 $(0.7 \%)$ 、口内乾燥 23 件 $(0.6 \%)$ 、閃光 感 20 件 $(0.5 \%)$ 、潮紅 18 件 $(0.5 \%$ )、疼症 18 件 $(0.5 \%)$ 、 嘔吐 14 件 $(0.4 \%)$ 、頭痛 9 件 $(0.2 \%)$ 、䕒麻疹 5 件 $(0.1 \%)$ 、 BUN上昇 5 件 $(0.1 \%) 、 G O T$ 上昇 5 件 $(0.1 \%)$ 等であった。 （再審查終了時: 承認時抢よび使用成績調查 [1985 年 11 月〜1991年11月]の累計)

薬価基準収載

その他詳細は、製品添付文書をご参照下さい。

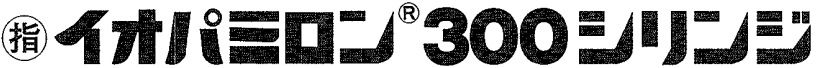
lopamiron 300 Syringe

(イオパミドール注射液)

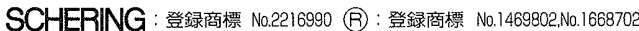

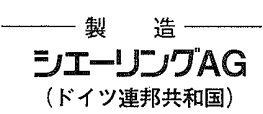

資料請求先 : 日本シエーリコブ株式会社 大阪市淀川区西宮原2丁目6番64号

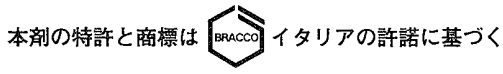
PAT. No. 1.097.667 1.109 .618

IPPFS0498

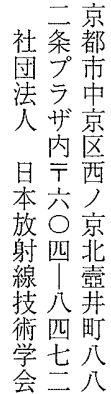

振振 $\mathrm{F}$ 電

替替 $\mathrm{A}$

$0 \mathrm{OX}$ 話

o. 00

八三立五

11 几

四五云0

$11 \equiv$

三三三 1

八六四三

会垈

㵒䓯

座

定制編

価 作集

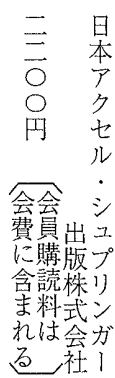

